\title{
Fluoretação da água de abastecimento público: custos de implementação e manutenção versus direito à água fluoretada
}

Recebido: 28 jan 2019 Aceito: 10 fev 2019

Autor de correspondência: lorraynebelotti@usp.br

Conflito de interesses: Os autores declaram não haver nenhum interesse profissional ou pessoal que possa gerar conflito de interesses em relação a este manuscrito.

\section{Resumo}

A fluoretação da água de abastecimento público é uma das medidas mais amplas de prevenção da cárie dentária em populações sendo considerada uma importante conquista da saúde pública mundial. Além disso, faz parte da agenda política internacional sendo considerada uma estratégia equitativa que deve ser desenvolvida e implantada em países que ainda não apresentam programas de fluoretação da água de abastecimento público. Porém, no Brasil, a população não dispõe do benefício da fluoretação de maneira igualitária em todo território brasileiro e essa distribuição irregular do recurso preventivo aumentou, ainda mais, o viés socioeconômico na prevalência da doença e a não universalidade mantém um enorme contingente populacional à margem do benefício. Comparando-se as regiões do País, são expressivas as diferenças nas médias do índice de dentes cariados, perdidos e obturados (CPO-D) aos 12 anos: as regiões Norte (com 3,16) e Nordeste (com 2,63) e também o Centro-Oeste (com 2,63) têm situação pior que as regiões Sudeste $(1,72)$ e Sul $(2,06)$. Ao mesmo tempo, essa desigualdade se estende para cobertura da população beneficiada por água de abastecimento público fluoretada, principalmente entre as capitais das regiões Norte e Nordeste em relação ao Sudeste e Sul. Estudos também revelam que quanto maior a cobertura do sistema de abastecimento de água, menor o CPO-D aos 12 anos. Ademais, evidências científicas comprovam que a experiência de cárie dentária em adultos que residem em cidades com água de abastecimento público fluoretada é menor em comparação com adultos de cidades sem esse benefício. Essa diferença expressa a injustiça social envolvida no não atendimento da determinação legal de fluoretação para todos os municípios. Entretanto, apesar das comprovações científicas acerca desta importante medida de saúde pública, um motivo alegado pelas companhias de abastecimento de água que impede o aumento da cobertura da população beneficiada pela fluoretação está relacionado com os custos da instalação do sistema de ajuste da concentração, da aquisição do produto químico e da capacitação profissional. Objetivo: o objetivo deste estudo foi analisar os custos da fluoretação da água de abastecimento público em diferentes contextos sociais, econômicos e demográficos. Métodos: para alcançar os objetivos traçados neste estudo, foi realizada uma revisão integrativa da literatura. Esse método de pesquisa permite 
a síntese de diversos estudos publicados em dado momento a respeito de uma temática específica. A revisão foi constituída de cinco fases: elaboração da pergunta norteadora; busca ou amostragem na literatura; revisão e seleção dos estudos; análise de dados; e apresentação dos resultados. A questão norteadora para busca das evidências científicas foi: "O que a literatura científica aborda, do ponto de vista econômico, sobre a fluoretação da água de abastecimento público?". Para identificar estudos relevantes, foi realizada pesquisa nas bases de dados: Literatura Cientifica e Técnica da América Latina e Caribe - LILACS, Publicações Médicas - PubMed, Scopus e Scientific Eletronic Library Online SciELo. A busca ocorreu, por meio da utilização conjunta dos Descritores em Ciências da Saúde - DeCS: "economia", "economia em odontologia", "custos", "custos e análise de custos", "análise de custo benefício" e "fluoretação", em inglês e português, a depender da solicitação da base de dados pesquisada. Não houve restrição de idiomas e os critérios de inclusão para a elaboração do presente estudo foram: resumos disponíveis, e disponibilidade do texto na íntegra. Não houve restrição de período de busca e foram excluídos trabalhos na modalidade de pesquisa bibliográfica, revisões, monografias, teses, dissertações. Resultados: inicialmente, foram encontrados 697 artigos nas quatros bases de dados, destes, 217 eram duplicados e, por isso, foram excluídos. Foram avaliados 480 títulos e resumos, destes, 436 foram excluídos pois não apresentavam questões econômicas relacionadas a fluoretação da água. Portanto, 36 artigos foram selecionados pelos resumos e títulos, entretanto, 15 estavam indisponíveis para leitura na íntegra e, apenas 21 foram selecionados para avaliação do texto completo. Após a leitura, dois foram excluídos, pois não traziam os custos para fluoretação, apenas discutiam os custos evitados ao fluoretar a água de abastecimento público. Portanto, 19 artigos foram selecionados para análise dos dados. Destes, sete foram publicados entre anos de 1974 e 2000, cinco publicados entre 2001 e 2010 e sete entre o período de 2011 a 2017. Ainda, 16 foram publicados no idioma inglês, dois em espanhol e um em português. Cinco estudos foram desenvolvidos na Austrália, cinco nos EUA, dois na Nova Zelândia, dois no Brasil, dois na Espanha, um no Chile, um na África do Sul e um na Inglaterra. Dentre os artigos selecionados, cinco eram sobre o custo-benefício da medida, seis sobre o custo-efetividade e oito eram apenas sobre custos. Considerações finais preliminares: a sintetização e avaliação de artigos que discutem os custos fluoretação, permitirá o avanço dos conhecimentos científicos no Brasil e no mundo, uma vez que as informações produzidas poderão auxiliar gestores das empresas públicas e privadas e demais tomadores de decisão com responsabilidade junto ao setor de saneamento em diferentes regiões do mundo.

Descritores: Economia da Saúde; Custos e Análise de Custo; Análise CustoBenefício; Fluoretação. 